Int. J. Dev. Biol. 57: 845-852 (2013)

doi: $10.1387 / \mathrm{ijdb} .130128 \mathrm{~s} 1$

\title{
The Oct4 promoter-EGFP transgenic rabbit: a new model for monitoring the pluripotency of rabbit stem cells
}

\author{
MINGRU YIN, ZHENFU FANG, WEIHUA JIANG, FENGYING XING, MANXI JIANG, PENGCHENG KONG, YAO LI, \\ XIAOMEI ZHOU, LAN TANG, SHANGANG LI* and XUEJIN CHEN* \\ Department of Laboratory Animal Sciences, School of Medicine, Shanghai Jiao Tong University, Shanghai, China
}

\begin{abstract}
The rabbit has long been used as a laboratory animal model for developing reproductive and stem cell-related technologies, as well as for studying human disease. The Oct4 transcription factor plays a crucial role in the maintenance and regulation of pluripotency in embryos and stem cells. We constructed a reporter plasmid containing the gene encoding the enhanced green fluorescent protein (EGFP) under the control of the rabbit Oct4 promoter (prOG) and transfected it into E14 mouse stem cells and rabbit ESCs. In addition, prOG transgenic fibroblasts were derived and prOG transgenic rabbits were produced by somatic cell nuclear transfer (SCNT). The pattern of expression of ectopic EGFP was similar in E14 mouse stem cells whether under the control of the rabbit (prOG) or mouse Oct4 promoter (pmOG). EGFP expression was observed in rabbit ESCs following prOG transfection. Both prOG transgenic SCNT embryos and F1 prOG transgenic embryos derived from adult transgenic rabbits expressed green fluorescence at the morula and blastocyst stages. EGFP was clearly detected in gonads isolated from fetuses at $27 \mathrm{dpc}$. The prOG transgenic rabbit represents a new model for studying the derivation and maintenance of rabbit pluripotent cells, and for investigating rabbit embryo development.
\end{abstract}

KEY WORDS: Oct4, rabbit, stem cell, EGFP, development

\section{Introduction}

Embryonic stem (ES) cells are capable of self-renewal and differentiation into many different cells and tissues comprising all three germ layers, both in vitro and in vivo. Therefore, ES cells are important for research into developmental biology, cell-based therapies, and genetic engineering (Do and Scholer, 2009). Since the first successful murine experiments (Evans and Kaufman, 1981, Martin, 1981), ES cell lines have been successfully established in a number of species, including humans, monkeys, and rats (Thomson et al., 1998). Recently, a new method was established for producing induced pluripotent stem (iPS) cells from mouse somatic cells by overexpressing four key transcription factors (Takahashi and Yamanaka, 2006). Within a year, human iPS cell lines were created using the same technology (Takahashi et al., 2007). Now iPS cells have been successfully produced from many other species (Ezashi et al., 2009, Honda et al., 2010, Liu et al., 2008, Sumer et al., 2010). Further improvements in ES and iPS cell techniques will enable cell-based therapies to be developed (Grigoriadis et al., 2010, Zou et al., 2011). Animal models will play important roles in the preliminary testing of novel ES or iPS cell-based therapies, which is required for ethical approval to be granted for clinical trials (Okamoto and Takahashi, 2011, Zou et al., 2011). Rabbits have several attractive features of small animal models, such as easy housing and handling. In addition, rabbits are preferentially used in cardiovascular, metabolic, myocardial, and pulmonary studies (Largo et al., 2008, Shimizu et al., 2009). While rabbit ES-like cells share many characteristics of true ES cells (Wang et al., 2007) and rabbit iPS cells have been generated (Honda et al., 2010, Osteil et al., 2013), more research into establishing rabbit ES cell lines is required.

Oct4, a member of the POU (Pit-Oct-Unc) family of transcription factors, is widely used as a pluripotent cell marker in many species (Wuensch et al., 2007, Zuccotti et al., 2012). Oct4 plays a crucial role in transcriptional regulation during early embryonic development and in cell differentiation (Kellner and Kikyo, 2010,

\footnotetext{
Abbreviations used in this paper: BSA, bovine serum albumin; dpc, days postcoitum; EGFP, enhanced green fluorescent protein; ES, embryonic stem cell; FBS, fetal bovine serum; ICM, inner cell mass; iPS, induced pluripotent stem cell; PBS, phosphate-buffered saline; PGCs, primordial germ cells; RT, room temperature; SCNT, somatic cell nuclear transfer; ZGA, zygotic genomic activation.
}

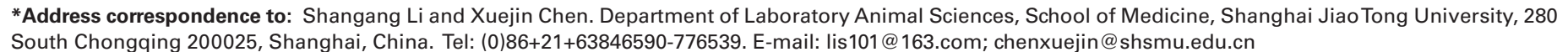


A

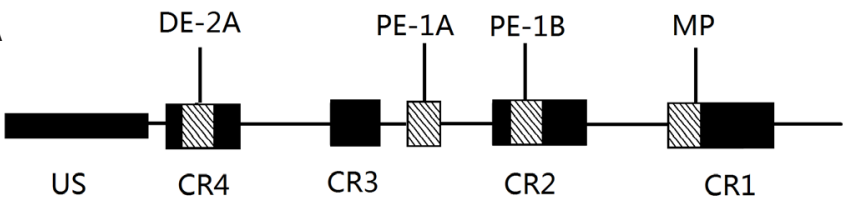

B

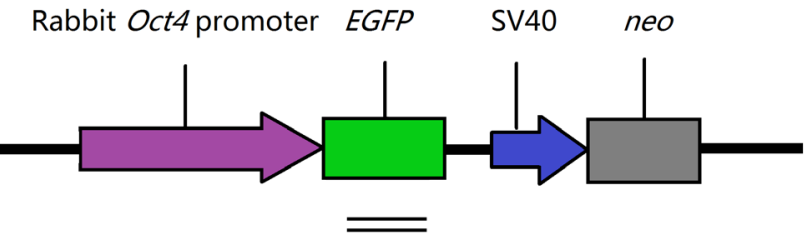

et al., 1998) and with murine PGC apoptosis (Kehler et al., 2004), suggesting an important role for Oct4 in the maintenance and self-renewal of pluripotent cell populations (Boiani and Scholer, 2005). Therefore, Oct4 is a good candidate gene for directing

A

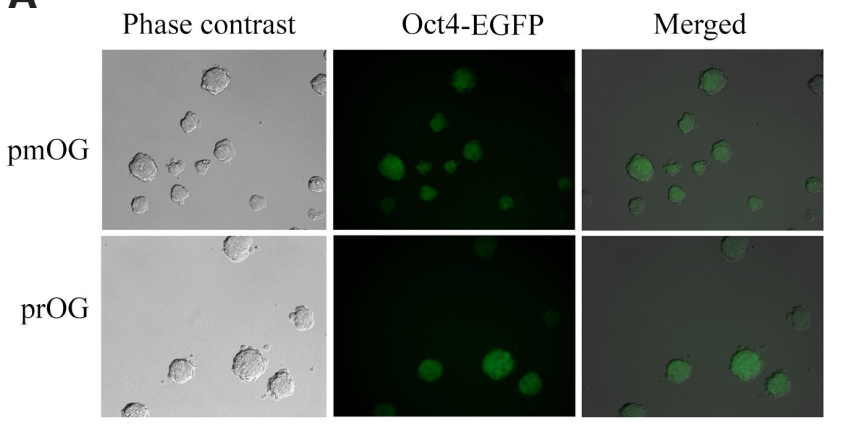

B
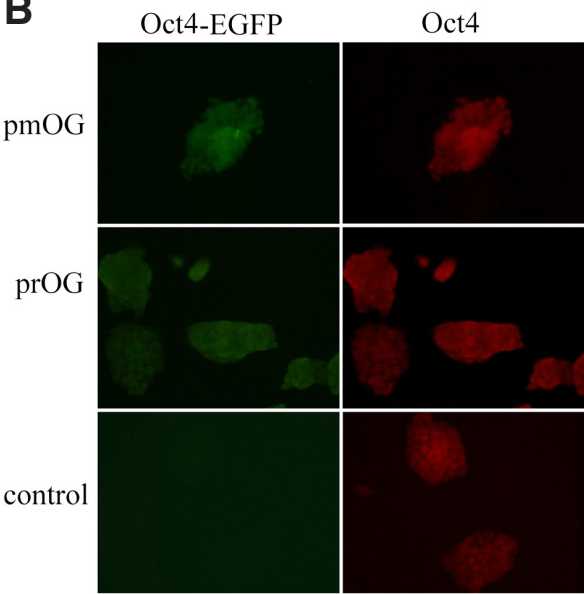

Hoechest 33342
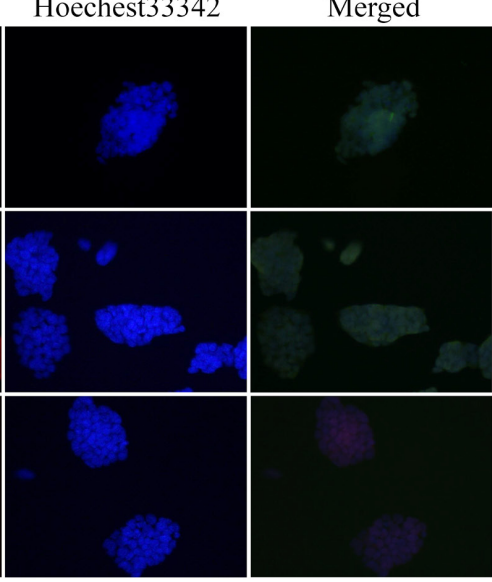

C

Phase contrast

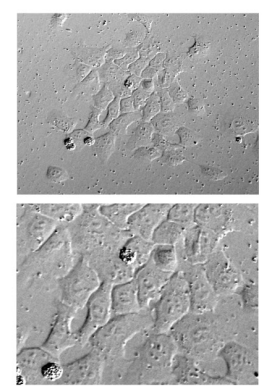

Oct4-EGFP
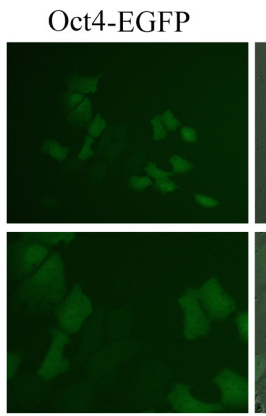

Fig. 1. Diagram of the rabbit Oct4 promoter and the prOG vector. (A) Diagram of the rabbit Oct4 upstream promoter region (approximately 3.2 kb; black bars represent conserved regions). There are four main elements: the distal enhancer (DE), the proximal enhancer (PE), and the minimal promoter (MP) and part of the upstream sequence (US). (B) Diagram of the prOG vector, containing the rabbit Oct4 promoter (approximately $3.2 \mathrm{~kb}$ ) followed by the EGFP gene (approximately $1 \mathrm{~kb}$ ) and a neomycin resistance gene (neo). The EGFP probe used for Southern blotting is indicated by double lines.

reporter gene expression in embryonic and pluripotent stem cells. The Oct4-enhanced green fluorescent protein (EGFP) mouse has revealed the timing and tissue specificity of Oct4 expression, and has been extremely valuable model for basic studies on pluripotency and differentiation (Yoshimizu et al., 1999). Subsequently, Oct4-EGFP reporter systems have been widely used for investigating the pluripotency and the reprogramming process in many other species, including human, mouse, pig and cattle (Berg et al., 2011, Nowak-Imialek et al., 2011, Ruiz et al., 2012, Scaldaferri et al., 2011, Youn et al., 2013).

The rabbit Oct4 cDNA and genomic DNA sequences are available and gene expression in preimplantation embryos has been characterized (Mamo et al., 2008, Shi et al., 2008). Moreover, the rabbit Oct45' regulatory region was sequenced and phylogenetically conserved regions were identified (Kobolak et al., 2009).

In this study, we constructed a prOG vector in which the rabbit Oct4 promoter controls expression of the gene encoding EGFP. The prOG transgenic embryos and rabbits were produced by somatic cell nuclear transfer (SCNT). Both prOG SCNT embryos and prOG $\mathrm{F} 1$ embryos derived from a transgenic rabbit expressed EGFP. In addition, green fluorescence was readily detected in gonads isolated from 27-dpc fetuses. We expect the prOG transgenic rabbit to be a useful animal model for studying the isolation and maintenance of rabbit pluripotent cells, and for conducting research into rabbit embryo development.

\section{Results}

\section{prOG and pmOG transfection induces similar pattern of EGFP expression}

A3.2 kb fragment of the Oct4 upstream promoter region was amplified from rabbit genomic DNA. Part of this sequence is highly homologous to rabbit Oct4 promoter regions identified by BLAST analysis (Kobolak et al., 2009) and contains four extensively conserved regions (CR1-4) and three main elements, the distal enhancer (DE), the proximal enhancer (PE), and the minimal promoter (MP). Another approximately $1 \mathrm{~kb}$ sequence upstream of the Oct4 promoter region was named US (upstream; Fig. 1A). In addition, the mouse Oct4 promoter was amplified from the mouse genome. These promoter fragments were used to construct prOG

Fig. 2. EGFP expression in mouse E14 cells and rabbit ESCs transfected with prOG or pmOG reporters. (A) EGFP fluorescence (EGFP) images of E14 cells transfected with pmOG and prOG. (B) Oct4 expression is assessed by immunofluorescence. Green, ectopic EGFP expression driven by the Oct4 promoter; red, endogenous Oct4; blue, Hoechst33342 staining. Untransfected E14 cells were used as controls. (C) Rabbit ESCs transfected with prOG reporter. 
A1

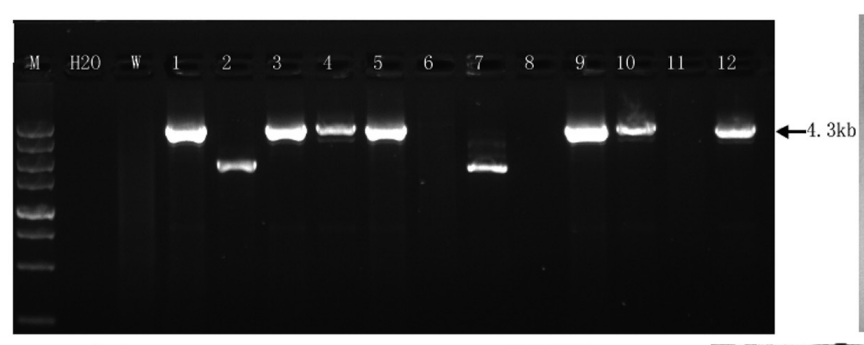

A2
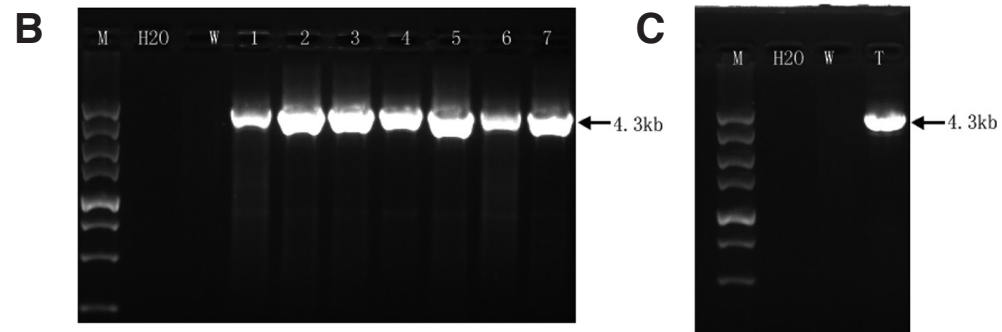

Fig. 3. PCR detection of Oct4 promoter-EGFP transgene. (A1) PCR analysis of DNA isolated from G418-resistant rabbit fetal fibroblasts stably transfected with the Oct4 promoter-EGFP transgene. M, DL5000 marker; W, wild-type rabbit fibroblasts (negative control); Lanes 1-12, G418-resistant rabbit cell clones. Positive clones were lines 1, 3, 4, 5, 9, 10, and 12 (indicated by band of approximately $4.3 \mathrm{~kb}$ ). (A2) Southern blot analysis of genomic DNA from PCR-positive cell clones showing hybridization with the EGFP probe after Xbal digestion. W, wild-type rabbit (negative control); Lanes 1-3: transgenic cell line 1, 3, and 5. The arrow marks the labeled $2.4 \mathrm{~kb}$ fragment. (B) PCR analysis of DNA isolated from stillborn transgenic rabbits. $M, D L 5000$ marker; W, wild-type rabbit; Lanes 1-7, Oct4-EGFP stillborn transgenic rabbits. (C) PCR analysis of the surviving transgenic rabbit. M, DL5000 marker; W, wild-type rabbit; T, Oct4-EGFP transgenic rabbit.

(rabbit Oct4 promoter-EGFP; Fig. 1B) and pmOG (mouse Oct4 promoter-EGFP) vectors.

EGFP expression was observed in E14 mouse ES cells 2 days after transfection with either the prOG or pmOG vector. After G418 selection, stably transfected clones were mechanically isolated and subcultured. Green fluorescence was detected in E14 mouse ES cells transfected with either the prOG or pmOG vector (Fig. 2A). Oct4 expression in Oct4-EGFP transgenic mouse ES cells was assessed by immunofluorescence (Fig. 2B). These data confirm that both reporter vectors function correctly and that prOG is a specific marker for Oct4-expressing cells.

\section{prOG transfection induces EGFP expression in rabbit ESCs}

The prOG vector was transfected into rabbit ESCs using Lipofectamine 2000 (Invitrogen, Carlsbad, CA, USA). EGFP expression was observed in rabbit ESCs 2 days after transfection (Fig. 2C). However, following G418 selection, stably transfected clones were not obtained owing to cell differentiation.

\section{The prOG construct is stably integrated into rabbit fibroblasts}

Next, the prOG vector was transfected into rabbit fibroblasts to assess EGFP expression in embryos and rabbits obtained following SCNT. As expected, no fluorescence was observed in prOG-transfected fibroblasts. A total of 12 stably transfected clonal cell lines were obtained following 7-10 days of G418 selec-

tion. DNA was isolated from all cell lines and transgene integration was assessed by PCR. Seven cell clones were found to contain the entire exogenous rabbit Oct4 promoter-EGFP sequence (approximately $4.3 \mathrm{~kb}$; Fig. 3 A1). PrOG integration was confirmed in three fastgrowing transgenic cell lines $(1,3$, and 5$)$ by Southern blotting using an EGFP probe (about $412 \mathrm{bp}$ ). The labeled fragment was about 2.4 kb (Fig. 3 A2). These data demonstrate that the EGFP fragment from the prOG plasmid is integrated into rabbit genome.

\section{EGFP is expressed in both SCNT embryos and prOG transgenic rabbits}

Two fast-growing transgenic cell lines were used as donor cells for SCNT. The total cleavage rate was $69.7 \%$ in cell line 1 and $73.6 \%$ in cell line 5 . Further, the total blastocyst rate was $23.7 \%$ in cell line 1 and $21.1 \%$ in cell line 5 (Table 1). Green fluorescence was clearly observed in all morulae and blastocysts from SCNT (Fig. 4). EGFP was detected in both the ICM and trophectoderm of blastocysts. Parthenogenetic blastocysts were used as controls.

\section{Production of prOG transgenic rabbits}

A total of 177 SCNT embryos derived from two transgenic cell lines were transferred to pseudopregnant rabbits. Of the eight recipient rabbits, three had successful pregnancies and eight kits were delivered. Of these, one transgenic male rabbit survived for at least 1 year (up to the time of manuscript preparation; Table 1). The prOG transgene was analyzed in seven stillborn rabbits (Fig. 3B) and in the surviving rabbit (Fig. 3C) by PCR.

1

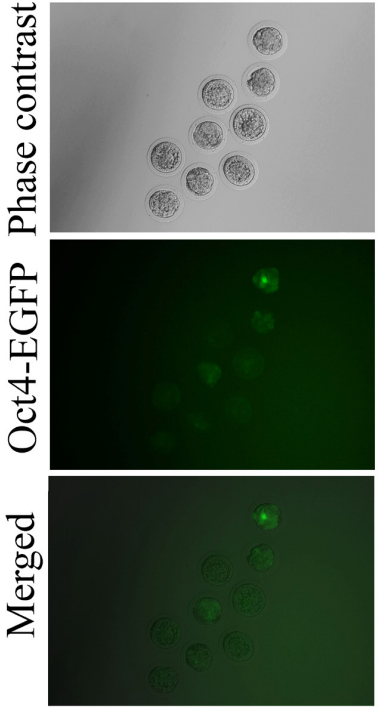

Fig. 4. EGFP expression in transgenic embryos. (1) SCNT embryos reconstructed using transgenic cell lines. (2) EGFP expression in the inner cell mass and the trophectoderm at the blastocyst stage. Parthenogenetic rabbit embryos were used as controls. 
A

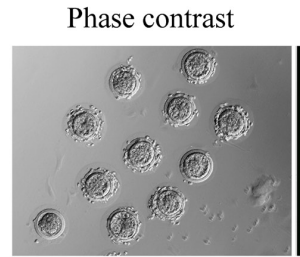

B
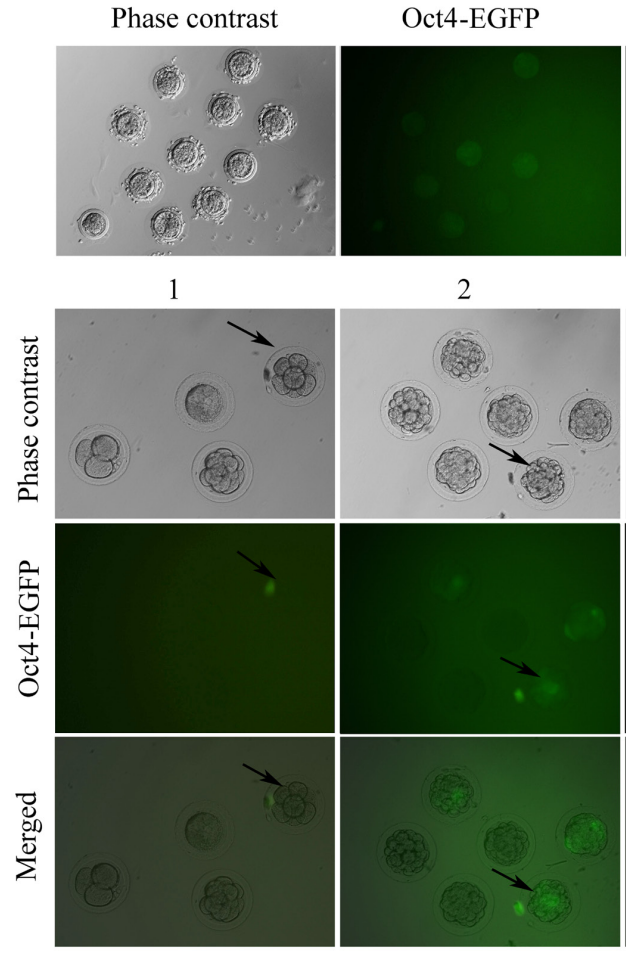

2

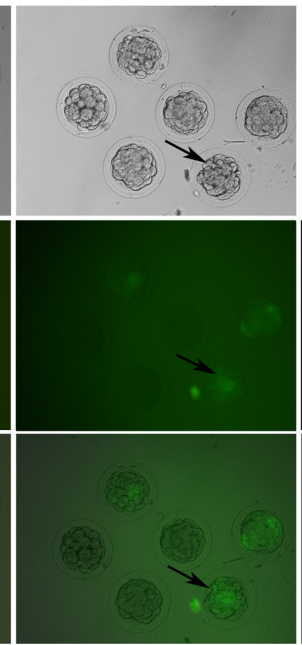

Merged

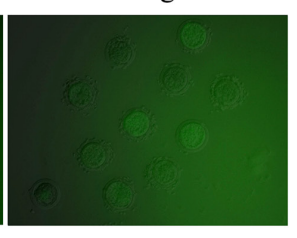

3

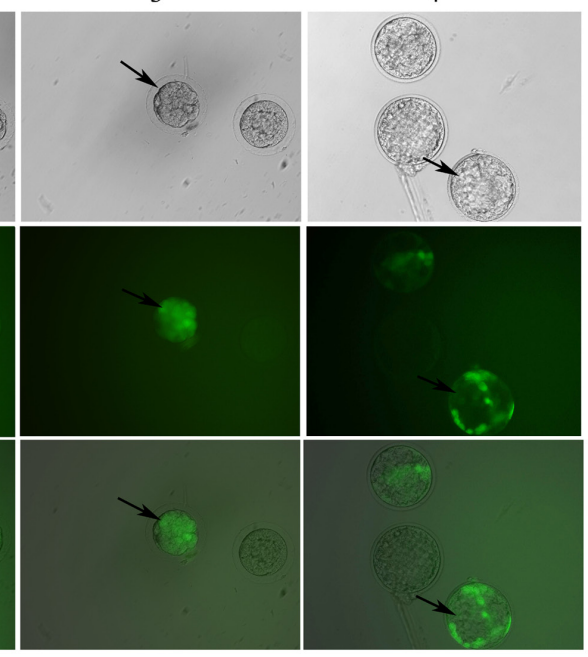

4

Fig. 5. EGFP expression in cultured F1 embryos at different developmental stages. (A) EGFP expression in areas of cultured F1 embryos from a prOG transgenic rabbit. (B) EGFP expression in different stage in vitro cultured $\mathrm{F} 1$ embryos from prOG transgenic rabbit. EGFP expression was not observed prior to the 16-cell stage (B1). EGFP expression is observed at the 16- to 32-cell stage (B2) and increases at the morula (B3) and blastocyst (B4) stages. (Arrows indicate EGFP expression in a single transgenic embryo at different stages)

the morula and blastocyst stages (Fig. 5 B3,4).

\section{Reporter expression is temporally and spatially similar to endogenous Oct4 expression}

To determine whether EGFP expression driven by the rabbit Oct4 promoter resembles endogenous Oct4 gene expression, EGFP-expressing $\mathrm{F} 1 \mathrm{em}$ bryos and wild-type controls at different developmental stages were assessed by immunofluorescence using an antiOct4 antibody. As expected, all prOG embryos expressed endogenous Oct4 at the 16-cell and blastocyst stages (Fig. 6). Oct4-EGFP reporter expression was similar to endogenous Oct4 expression

The Oct4-EGFP transgene is transmitted in the germ line

Germ line transmission was assessed by mating the transgenic rabbit with wild-type females. One day after mating, fertilized embryos were harvested and cultured in vitro. After two days, approximately $52.5 \%$ (31 of 59) of the F1 embryos expressed EGFP (Fig. 5A). Furthermore, stage-specific EGFP expression was observed in cultured $F 1$ embryos derived from a prOG transgenic rabbit. EGFP expression was not observed before the 16-cell stage (Fig. 5 B1). At the 16- to 32-cell stage, EGFP expression is observed (Fig. 5 B2), which increases at

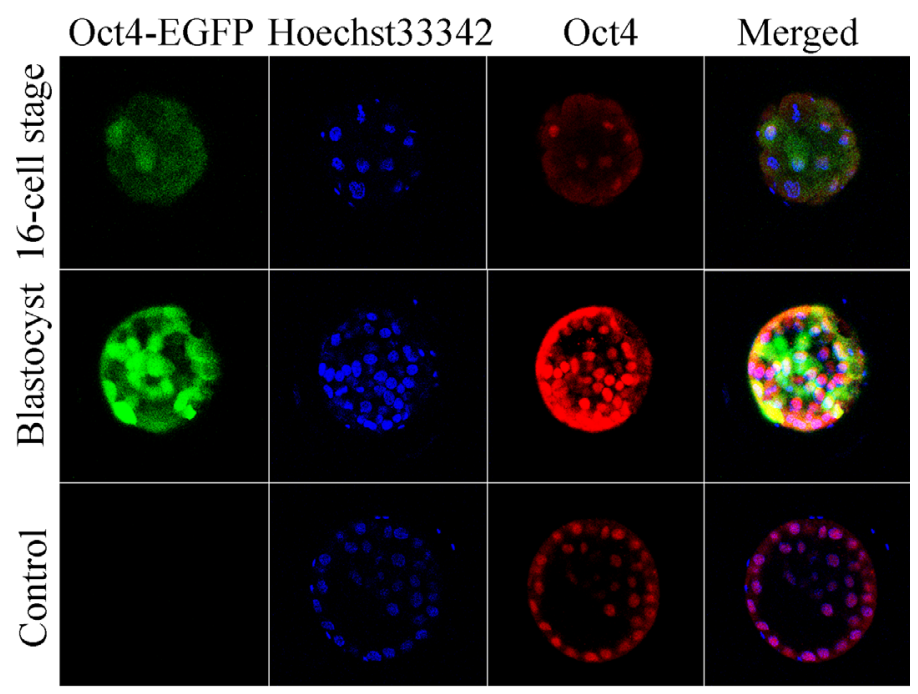

Fig. 6. Oct-4expression in prOG transgenic embryos. AllprOG embryos at the 16-cell or blastocyst stages expressing ectopic Oct4-EGFP (green) also expressed endogenous Oct4 (red). Nuclei are indicated by Hoechst33342 nuclear staining (blue). Normal blastocysts were used as control. with respect to localization and developmental stage.

\section{EGFP expression in the gonads of Oct4-EGFP trans- genic fetuses}

The germinal tissues of Oct4-EGFP transgenic fetuses at $15 \mathrm{dpc}$ and $27 \mathrm{dpc}$ were isolated and EGFP expression was analyzed. No green fluorescence was detected in the germinal ridges, which are connected with the mesonephros, but green fluorescence was detected in several cells between the two genital ridges in the fetus at $15 \mathrm{dpc}$ (Fig. 7A). However, when the testes and ovaries isolated from fetuses at $27 \mathrm{dpc}$ were analyzed, green fluorescence was clearly detected in the seminiferous tubules of the testes (Fig. 7B) and punctate green fluorescence was observed in the cortex of the ovaries (Fig. 7C). No green fluorescence was detected in any of the other tissues tested, including the heart, liver, and skin (data not shown). prOG transgene integration and sex were confirmed by PCR and morphological analysis, respectively. Transgenenegative gonads from $27-d p c$ fetuses were used as controls.

\section{Discussion}

In this study, an Oct4-EGFPreporter system was developed and the first transgenic Oct4-EGFP rabbit was made. The prOG transgenic rabbit is a useful tool for monitoring Oct4 expression in embryonic and pluripotent stem cells. ES or iPS cells derived from the prOG rabbit will enable the mechanisms controlling rabbit pluripotent stem maintenance and reprogramming required for iPS production to be studied.

The upstream region of the rabbit Oct4 gene was subcloned and four highly conserved promoter regions (CR1-4) were identified, as previously reported (Kobolak et al., 2009). Sequence alignment of the mouse, human, and bovine Oct4 
TABLE 1

\section{SUMMARY OF NUCLEAR TRANSFER RESULTS USING PROG TRANSGENIC FIBROBLASTS}

\begin{tabular}{|c|c|c|c|c|c|c|c|}
\hline Donor cell lines & $\begin{array}{c}\text { No. of reconstructed } \\
\text { embryos }\end{array}$ & Cleavage (rate) & Blastocyst ( rate) & $\begin{array}{l}\text { No. of embryos } \\
\text { transferred }\end{array}$ & $\begin{array}{l}\text { No. of recipients } \\
\text { recipients }\end{array}$ & $\begin{array}{c}\text { No. of pregnant } \\
\text { recipients }\end{array}$ & $\begin{array}{l}\text { No. of live/ stillborn or } \\
\text { postnatal deaths rabbits }\end{array}$ \\
\hline Cell line 1 & 76 & $53(69.7 \%)$ & $18(23.7 \%)$ & & & & \\
\hline Cell line 1 & 229 & $168(73.3 \%)$ & & 134 & 6 & 3 & $1 / 7$ \\
\hline Cell line 5 & 19 & $14(73.6 \%)$ & $4(21.1 \%)$ & & & & \\
\hline Cell line 5 & 59 & $43(72.8 \%)$ & & 43 & 2 & 0 & 0 \\
\hline
\end{tabular}

upstream promoter sequences and pairwise comparisons of the rabbit Oct4 regulatory regions with equivalent murine, bovine, canine, and human sequences revealed a high level of Oct4 sequence conservation. The highest degree of sequence similarity was found in the conserved domains between rabbit and human. However, differences in some regions were found, especially in the $\mathrm{PE}$ region. A previous analysis of the rabbit Oct4 promoter showed that different regions can induce different levels of reporter expression in mouse ES cells (Kobolak et al., 2009). The CR4 region is responsible for Oct4 expression in ES cells (Yeom et al., 1996). To monitor Oct4 expression in rabbit, we decided to express EGFP under the control of the entire rabbit Oct4 promoter (approximately $3.2 \mathrm{~kb}$, including approximately $1 \mathrm{~kb}$ more upstream sequence than the reported Oct4 promoter region) to maximize reporter expression, increase the efficiency of exogenous transgenes, and maintain integrity of the CR4 region.

Well-established techniques are available for isolating and studying mouse ES cells. We therefore constructed the pmOG vector, containing the mouse Oct4 promoter and EGFP, for comparing with the prOG vector. Both prOG and pmOG reporters were transfected into $E 14$ mouse ES cells and the pattern of reporter expression was assessed by EGFP fluorescence. Both prOG and pmOG reporters were expressed at similar pattern in mouse ES cells. This study
Phase contrast

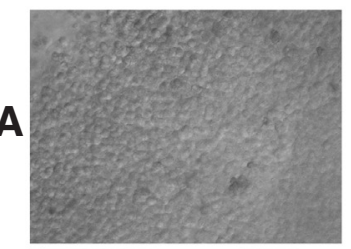

B
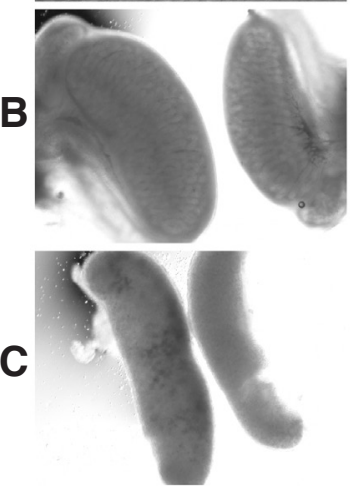

Oct4-EGFP
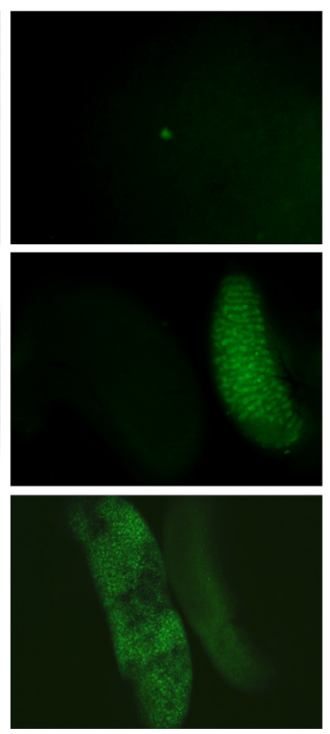

Merged
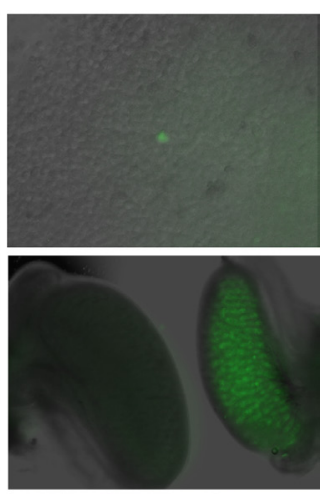

Fig. 7. EGFP expression in fetal tissues or organs at different developmental stages. (A) EGFP expression in a single cell located between two genital ridges in a 15-dpc fetus. (B) EGFP expression in the testis of a 27-dpc fetus. Right, testis from a prOG transgenic fetus; left, testis from a normal fetus. (C) EGFP expression in the ovary of a 27-dpc fetus. Right, ovary from a normal fetus; left, ovary from a prOG transgenic fetus. clearly shows the high degree of homology that exists between Oct4 genes of different species and the similar level of activity of the rabbit and mouse promoter sequences (prOG and pmOG). In parallel experiments, rabbit ESCs were transfected with the prOG vector. The results confirm that EGFP is expressed in rabbit ESCs.

In an attempt to establish prOG transgenic rabbit fibroblasts, we chose two cell lines with intact Oct4-EGFP sequences for SCNT experiments. All transgenic SCNT embryos expressed EGFP and all prOG transgenic rabbits, both live and stillborn, contained the entire Oct4 promoter-EGFP sequence. The results indicate that the rate of transgenic animal production can be improved by monoclonal selection of transfectants coupled with PCR and Southern blot confirmation of transgene integration.

SCNT and F1 blastocyst analysis revealed EGFP expression in both the ICM and trophectoderm (Fig. 4-2, Fig. 6), similar to previous reports of endogenous Oct4 mRNA expression (Kobolak et al., 2009). The pattern of Oct4 expression in blastocysts differs among species. For example, Oct4 protein is detectable in the ICM but not the trophectoderm of in vivo-derived murine embryos; in contrast, Oct4 protein is expressed in both the ICM and the trophectoderm of in vivo- and in vitro-derived porcine and bovine blastocysts (Kirchhof et al., 2000). Previous studies have analyzed Oct4 expression in rabbit embryos using RT-PCR (Mamo et al., 2008) and immunostaining (Chen et al., 2012). Oct4 is expressed at the zygote stage, and expression decreases gradually until zygotic genomic activation (ZGA) (8-16-cell stage for rabbits) and then increases up to the blastocyst stage. In this study, EGFP expression was first observed at the 16- to 32-cell stage, and then increased up to the morula and blastocyst stages in F1 transgenic embryos (Fig.5B-2, $3,4)$. This indicates that expression of the paternal Oct4 gene commences with ZGA in rabbit embryos. The initial development of mammalian embryos is governed by gene transcripts and polypeptides produced by and stored in the oocytes during oogenesis (Schultz, 1993). Following cleavage, the amount of maternally derived transcripts and proteins gradually decreases (De Sousa et al., 1998) and transition from maternal to embryonic gene expression occurs. In rabbits, ZGAoccurs at the 8-16-cell stage, more than $44 \mathrm{~h}$ after fertilization (Pacheco-Trigon et al., 2002). In the present study, a lack of EGFP expression before the 8-cell stage suggests that the integrated Oct4-EGFP sequence is not fully activated. Overall, Oct4-EGFP transgene expression is consistent with that of zygotic Oct4 in early stage embryos. Furthermore, the IF results confirm that the pattern of EGFP expression driven by the rabbit Oct4promoter resembles that of endogenous Oct4gene expression (Fig. 6). Following Oct4EGFP transgene expression, GFP is distributed throughout the entire cell. However, Oct4 is a nucleoprotein; therefore, the GFP signal in Oct4-EGFP transgenic cells covers a much 
larger area than does nuclear Oct4 immunofluorescence staining. Nevertheless, the expression patterns of the Oct4 reporter and the endogenous Oct4 gene are similar.

Germline EGFP expression analysis was done using isolated 15-dpc and 27-dpc fetuses. Surprisingly, no green fluorescence was detected in the genital ridges, although it was observed in several cells located between the two genital ridges in the fetus at $15 \mathrm{dpc}$ (Fig. 7A). These green fluorescence cells may be PGCs that have not entered the genital ridges, but we cannot explain the absence of green fluorescence in the genital ridges. However, green fluorescence was clearly detected in testes and ovaries isolated from a 27-dpc fetus (Fig. 7B,C). The EGFP expression pattern is consisted with recent Q-PCR data of rabbit Oct4 (Daniel-Carlier et al., 2013). The level of Oct4 expression was low in the early stage (at $14 \mathrm{dpc}$ ) differentiated gonad and the maximum level of expression was found at around 24-28 dpc in both testes and ovaries. In contrast, OCT4 expression is downregulated in female mice at $14.5 \mathrm{dpc}$ (Pesce et al., 1998) and GFP expression driven by the murine Oct4 promoter is undetectable at $17.5 \mathrm{dpc}$ (Yoshimizu et al., 1999). These results show that the timing of OCT4 protein expression differs between mouse and rabbit fetal development.

We have therefore demonstrated that the Oct4-EGFP transgene is an appropriate method for studying Oct4 expression in pluripotent cells. In conclusion, we have successfully produced an Oct4-EGFP transgenic rabbit, which provides a useful tool to monitor pluripotency in rabbit pluripotent cells.

\section{Materials and Methods}

\section{Reagents}

All media were purchased from Gibco (Grand Island, N.Y. USA) and all chemicals were purchased from Sigma-Aldrich (St. Louis, MO, USA), unless otherwise stated. All animal experiments including animal care, the SCNT protocol, embryo transfer, and cesarean sections were carried out according to guidelines of the Ethics Committee of Shanghai Jiao Tong University, School of Medicine.

\section{Reporter plasmid construction}

The rabbit Oct4 promoter (approximately 3.2 kb; GenBank NW_003159279.1) and mouse Oct4 promoter (approximately 2.3 kb; GenBank AJ297528.1) were PCR amplified using the following primers:

rOCT4-F, 5'-GCGattaatAGACCCAGGAGACTCAAAG-3'; rOCT4-R, 5'-ATAgctagcGGGGGAAGGAGGGCGCCCCGC-3'; mOCT4-F, 5'-AGCTattaatACGCTTAGGGCTAACCTGG-3'; and mOCT4-R, 5' -CTAgctagcTGGTGGAAAGACGGCTCAC-3'.

Genomic DNA was isolated from New Zealand rabbit and C57BL/6J mouse fetal fibroblast cells using a MiniBEST Universal Genomic DNA Extraction Kit (TaKaRa, Dalian, China). Premix long and accurate (LA) PCR (TaKaRa) was performed with the following cycling conditions: 10 min at $98^{\circ} \mathrm{C} ; 35$ cycles of $98^{\circ} \mathrm{C}$ for $10 \mathrm{~s}, 68^{\circ} \mathrm{C}$ for $30 \mathrm{~s}$, and $72^{\circ} \mathrm{C}$ for $3 \mathrm{~min}$; and $72^{\circ} \mathrm{C}$ for $10 \mathrm{~min}$. The amplified Oct4 promoter was digested by Asel and Nhel, the CMV promoter in the pEGFPC1 vector (catalog no. 6084-1, Clontech) was removed by Asel and Nhel digestion, and the Oct4 promoter was then cloned into the PEGFPC1 vector. The prOG and PmOG vector sequences were confirmed by restriction digest and DNA sequencing.

\section{Transfection of mouse E14 cells}

Mouse E14 stem cells (obtained from Dr. Junling Liu) were cultured in DMEM/F12 supplemented with $100 \times$ NEAA, $2 \mathrm{mM}$ glutamine, $0.1 \mathrm{mM} \beta$ mercaptoethanol, $15 \%$ fetal bovine serum (FBS), and $100 \mathrm{U} / \mathrm{mL}$ leukemia inhibitory factor without feeder cells. For transfection, approximately $1 \times 10^{5}$ cells E14 cells were seeded into $3.5-\mathrm{cm}$ dishes. One day later, cells were transfected with $2 \mu \mathrm{g}$ plasmid DNA using Lipofectamine 2000 (Invitrogen, Carlsbad, CA, USA) according to the manufacturer's specifications. After $48 \mathrm{~h}$, cells were observed under fluorescence microscopy (IX71 equipped with UV: BH2-RFL-T3 major in $488 \mu \mathrm{m}$, Olympus, Japan). Stably transfected E14 clones were obtained by selection with $200 \mu \mathrm{g} / \mathrm{mL}$ G418 for 5-8 days, isolated mechanically, and maintained in culture.

\section{Transfection of rabbit ESCs}

Rabbit ESCs were isolated and cultured as previously reported with some modifications (Fang et al., 2006). The culture medium ESM consisted of $78 \%$ DMEM/F-12, 20\% Knockout serum replacement (Invitrogen, Carlsbad, CA), $2 \mathrm{mM}$ L-glutamine, $1 \%$ nonessential amino acids and $0.1 \mathrm{mM}$ $\beta$-mercaptoethanol was conditioned with mouse embryonic fibroblasts as reported (Denning et al., 2006, Hannoun et al., 2010). 4-8 ng/ml human recombinant bFGF (basic fibroblast growth factor) was added to the ESM before use. For transfection, confluent rabbit ESCs were seeded at a 1:5 dilution into $3.5-\mathrm{cm}$ dishes coated by Matrigel (Becton Dickinson Biosciences Clontech, Palo Alto, CA, USA). One day later, cells were transfected with $2 \mu \mathrm{g}$ plasmid DNA using Lipofectamine 2000 (Invitrogen, Carlsbad, CA, USA) according to the manufacturer's specifications. After $48 \mathrm{~h}$, cells were observed under fluorescence microscopy and $200 \mu \mathrm{g} / \mathrm{mL} \mathrm{G} 418$ was added to the culture medium for selection.

\section{Establishment of transfected fibroblasts}

The isolation, primary culture, and transfection of fibroblasts from a male New Zealand rabbit were described previously (Li et al., 2006, Li et al., 2009). Fibroblasts were cultured in DMEM/F12 supplemented with $10 \%$ FBS. For transfection, approximately $1 \times 10^{5}$ fibroblasts/well were seeded into 24-well tissue culture plates. The prOG plasmid was transfected into fibroblasts using Lipofectamine 2000. After $24 \mathrm{~h}$, cells were trypsinized and transferred into four 48 -well plates. When cells reached about $40 \%$ confluence, $1 \mathrm{mg} / \mathrm{mL}$ G418 was added to the culture medium. After 7-10 days of selection, surviving clones were analyzed by PCR and used for SCNT.

\section{Somatic cell nuclear transfer and embryo transfer}

The SCNT procedure was carried out as described previously ( $\mathrm{Li}$ et al., 2006), with some modifications. Briefly, oocytes were collected from superovulated mature white New Zealand female rabbits. Denuded oocytes were enucleated by removing the first polar body and the associated metaphase plate under an inverted microscope equipped with a Spindle View system (Cambridge Research \& Instrumentation Inc., USA). prOG transgenic fibroblasts cultured in serum starvation conditions (DMEM supplemented with $0.5 \%$ FBS) for $2-4$ days were used as donor cells. Donor cells were inserted into the perivitelline space of enucleated oocytes. Reconstructed embryos were electrofused in fusion buffer using two pulses ( $25 \mu \mathrm{s} \mathrm{DC} 2.0 \mathrm{KV} / \mathrm{cm}$ ) and cultured in $\mathrm{mRD}$ (RD medium supplemented with $10 \%$ FBS, $2 \mathrm{mM}$ glutamine, $223 \mu \mathrm{M}$ sodium pyruvate and $100 \mu \mathrm{M}$ NEAA). SCNT embryos were activated after $30 \mathrm{~min}$ by a second identical set of electric pulses and then cultured in mRD supplemented with $5 \mu \mathrm{g} / \mathrm{mL}$ cycloheximide and $2 \mathrm{mM} 6$-dimethylaminopurine for $1 \mathrm{~h}$. Finally, embryos were incubated with $\mathrm{mRD}$ for $1 \mathrm{~h}$, followed by incubation in B2 medium prepared as previously reported (Staessen et al., 1998) and supplemented with $5 \%$ FBS. Reconstructed embryos were either cultured in vitro to the blastocyst stage or transferred to pseudopregnant recipients. EGFP expression in embryos was detected by fluorescence microscopy. Between 8 and 15 reconstructed embryos at the 4 to 8 -cell stage were transferred into each oviduct of recipients through the infundibulum. Pregnancies were assessed after 14 and 29 days by palpation. Cesarean section was performed 31 days after embryo transfer.

\section{PCR analyses}

Genomic DNA was isolated from stably transfected cell lines and transgenic rabbits with a MiniBEST Universal Genomic DNA Extraction Kit (TaKaRa). PCR amplification was performed with Premix LATaq Version 2.0 (TaKaRa) and the primers Oct4JDF (5'-AGACCCAGGAGACTCAAAG-3') 
and Oct4JDR (5'-CGATTTCGGCCTATTGGTT-3'). PCR conditions were: $10 \mathrm{~min}$ at $98^{\circ} \mathrm{C}$; 35 cycles of $98^{\circ} \mathrm{C}$ for $10 \mathrm{~s}, 56^{\circ} \mathrm{C}$ for $30 \mathrm{~s}$, and $72^{\circ} \mathrm{C}$ for $5 \mathrm{~min}$; and $72^{\circ} \mathrm{C}$ for $10 \mathrm{~min}$. DNA fragment size was approximately 4.3 $\mathrm{kb}$. DNA isolated from wild-type rabbits was used as a negative control.

\section{Southern blotting}

A phenol-chloroform-isopentanol method was used to extract DNA from three transgenic rabbit fibroblast cell lines and normal rabbit fibroblasts. An EGFP DNA probe was amplified from the prOG plasmid with the following primers: GFPprobF, 5' -ACAAGTTCAGCGTGTCCG-3'; GFPprobR, 5' ${ }^{\prime}$ TTGATGCCGTTCTTCTGC-3'. Amplified DNA fragments (300 ng samples) were DIG labeled using a random primed labeling technique (DIG High Prime DNA Labeling and Detection Starter Kit I; Roche, Mannheim, Germany). Genomic DNA (20 $\mu \mathrm{g})$ was digested using Xbal (TaKaRa). For electrophoresis, a $1 \%$ agarose gel was loaded with genomic DNA samples and subjected to $80 \mathrm{~V}$ for $4 \mathrm{~h}$. Membrane transfer was carried out using an iBlot dry blotting system (Invitrogen, Israel). After prehybridization, the probe was added and hybridized at $56^{\circ} \mathrm{C}$. After $24 \mathrm{~h}$, membranes were washed and blocked, and the hybridized probe was immunodetected with anti-digoxigenin-AP and NBT/BCIP for visualization.

\section{Germline transmission analyses}

The male prOG transgenic rabbit was mated with wild-type female rabbits. Fertilized oocytes (F1) were obtained from four the female rabbits at 1 dpc. The embryos were cultured and used for EGFP expression analysis. For gonad expression analysis, fetuses were isolated at $15 \mathrm{dpc}$ and $27 \mathrm{dpc}$. The posterior section of the 15-dpc fetus was mounted onto a slide for EGFP expression analysis. Whole testes or ovaries were isolated from 27-dpc fetuses and mounted onto slides for EGFP expression analysis.

\section{Immunofluorescence and confocal imaging}

Cultured transgenic E14 and F1 embryos were used for immunofluorescence analysis of endogenous Oct4 expression, as previously reported (Chen et al., 2012, Oeda et al., 2013) with some modification. First, E14 cells and embryos were fixed by incubation with fresh $4 \%(\mathrm{v} / \mathrm{v})$ paraformaldehyde in phosphate-buffered saline (PBS) for $1 \mathrm{~h}$ at room temperature (RT) and permeabilized by incubating with $0.25 \%$ Triton X-100 overnight at $4{ }^{\circ} \mathrm{C}$. Next, E14 cells and embryos were blocked in PBS containing $0.3 \%$ bovine serum albumin (BSA) for $1 \mathrm{~h}$ at RT and incubated with anti-Oct4 antibody (1:150 dilution; MAB4401, Millipore, Billerica, MA, USA) overnight at $4^{\circ} \mathrm{C}$. E14 cells and embryos were then washed in three times for $30 \mathrm{~min}$ in PBS containing $0.3 \%$ BSA and incubated with secondary antibody for 2 $\mathrm{h}$ at RT. After another three washes, embryos were incubated with $10 \mu \mathrm{g} /$ $\mathrm{mL}$ Hoechst33342 for 20 min at RT, washed three times, and mounted on slides. E14 cells were observed by fluorescence microscopy and embryos were observed by laser scanning confocal microscopy (Zeiss LSM-510 with a 3-line laser: $488 \mathrm{~nm}, 543 \mathrm{~nm}$, and $790 \mathrm{~nm}$ ).

\section{Statement}

Semen samples and somatic cells from the Oct4-EGFP transgenic rabbit are available to academic researchers upon request.

\section{Acknowledgements}

The study was supported by grants from the Natural Science Foundation of China (Nos. 81170756, 31101048), the Shanghai Natural Science Funding (Nos. 11140901600, 11ZR1418800, 10140901700) and the National Transgenic Foundation of China (2011ZX08008-003).

\section{References}

BERG, D.K., SMITH, C.S., PEARTON, D.J., WELLS, D.N., BROADHURST, R., DONNISON, M. and PFEFFER, P.L. (2011). Trophectoderm lineage determination in cattle. Dev Cell 20: 244-255.

BOIANI, M. and SCHOLER, H.R. (2005). Regulatory networks in embryo-derived pluripotent stem cells. Nat Rev Mol Cell Biol 6: 872-884.
CHEN, C.H., CHANG, W.F., LIU, C.C., SU, H.Y., SHYUE, S.K., CHENG, W.T., CHEN, Y.E., WU, S.C., DU, F., SUNG, L.Y. etal., (2012). Spatial and temporal distribution of Oct-4 and acetylated H4K5 in rabbit embryos. Reprod Biomed Online 24: 433-442.

DANIEL-CARLIER, N., HARSCOET, E., THEPOT, D., AUGUSTE, A., PAILHOUX, E. and JOLIVET, G. (2013). Gonad differentiation in the rabbit: evidence of speciesspecific features. PLoS One 8: e60451.

DE SOUSA, P.A., WATSON, A.J., SCHULTZ, G.A. and BILODEAU-GOESEELS, S. (1998). Oogenetic and zygotic gene expression directing early bovine embryogenesis: a review. Mol Reprod Dev 51: 112-121.

DENNING, C., ALLEGRUCCI, C., PRIDDLE, H., BARBADILLO-MUNOZ, M.D., ANDERSON, D., SELF, T., SMITH, N.M., PARKIN, C.T. and YOUNG, L.E. (2006). Common culture conditions for maintenance and cardiomyocyte differentiation of the human embryonic stem cell lines, BG01 and HUES-7. Int J Dev Bio/50: 27-37.

DO, J.T. and SCHOLER, H.R. (2009). Regulatory circuits underlying pluripotency and reprogramming. Trends Pharmacol Sci 30: 296-302.

EVANS, M.J. and KAUFMAN, M.H. (1981). Establishment in culture of pluripotential cells from mouse embryos. Nature 292: 154-156.

EZASHI, T., TELUGU, B.P., ALEXENKO, A.P., SACHDEV, S., SINHA, S. and ROBERTS, R.M. (2009). Derivation of induced pluripotent stem cells from pig somatic cells. Proc Natl Acad Sci USA 106: 10993-10998.

FANG, Z.F., GAI, H., HUANG, Y.Z., LI, S.G., CHEN, X.J., SHI, J.J., WU, L., LIU, A., $X U, P$. and SHENG, H.Z. (2006). Rabbit embryonic stem cell lines derived from fertilized, parthenogenetic or somatic cell nuclear transfer embryos. Exp Cell Res 312: 3669-3682

GRIGORIADIS, A.E., KENNEDY, M., BOZEC, A., BRUNTON, F., STENBECK, G. PARK, I.H., WAGNER, E.F. and KELLER, G.M. (2010). Directed differentiation of hematopoietic precursors and functional osteoclasts from human ES and iPS cells. Blood 115: 2769-2776.

HANNOUN, Z., FLETCHER, J., GREENHOUGH, S., MEDINE, C., SAMUEL, K. SHARMA, R., PRYDE, A., BLACK, J.R., ROSS, J.A., WILMUT, I. et al., (2010). The comparison between conditioned media and serum-free media in human embryonic stem cell culture and differentiation. Cell Reprogram 12: 133-140.

HONDA, A., HIROSE, M., HATORI, M., MATOBA, S., MIYOSHI, H., INOUE, K. and OGURA, A. (2010). Generation of induced pluripotent stem cells in rabbits: potential experimental models for human regenerative medicine. $J$ Biol Chem 285: 31362-31369.

KEHLER, J., TOLKUNOVA, E., KOSCHORZ, B., PESCE, M., GENTILE, L., BOIANI, M., LOMELI, H., NAGY, A., MCLAUGHLIN, K.J., SCHOLER, H.R. et al., (2004) Oct4 is required for primordial germ cell survival. EMBO Rep 5: 1078-1083.

KELLNER, S. and KIKYO, N. (2010). Transcriptional regulation of the Oct4 gene, a master gene for pluripotency. Histol Histopathol 25: 405-412.

KIRCHHOF, N., CARNWATH, J.W., LEMME, E., ANASTASSIADIS, K., SCHOLER, $\mathrm{H}$. and NIEMANN, H. (2000). Expression pattern of Oct-4 in preimplantation embryos of different species. Biol Reprod 63: 1698-1705.

KOBOLAK, J., KISS, K., POLGAR, Z., MAMO, S., ROGEL-GAILLARD, C., TANCOS, Z., BOCK, I., BAJI, A.G., TAR, K., PIRITY, M.K. et al., (2009). Promoter analysis of the rabbit POU5F1 gene and its expression in preimplantation stage embryos. BMC Mol Biol 10: 88.

LARGO, R., SANCHEZ-PERNAUTE, O., MARCOS, M.E., MORENO-RUBIO, J., APARICIO, C., GRANADO, R., ORTEGA, L., EGIDO, J. and HERREROBEAUMONT, G. (2008). Chronic arthritis aggravates vascular lesions in rabbits with atherosclerosis: a novel model of atherosclerosis associated with chronic inflammation. Arthritis Rheum 58: 2723-2734.

LI, S., CHEN, X., FANG, Z., SHI, J. and SHENG, H.Z. (2006). Rabbits generated from fibroblasts through nuclear transfer. Reproduction 131: 1085-1090.

LI, S., GUO, Y., SHI, J., YIN, C., XING, F., XU, L., ZHANG, C., LIU, T., LI, Y., LI, H. et al., (2009). Transgene expression of enhanced green fluorescent protein in cloned rabbits generated from in vitro-transfected adult fibroblasts. Transgenic Res 18: 227-235.

LIU, H., ZHU, F., YONG, J., ZHANG, P., HOU, P., LI, H., JIANG, W., CAI, J., LIU, M., CUI, K. et al., (2008). Generation of induced pluripotent stem cells from adult rhesus monkey fibroblasts. Cell Stem Cell 3: 587-590.

MAMO, S., GAL, A.B., POLGAR, Z. and DINNYES, A. (2008). Expression profiles of the pluripotency marker gene POU5F1 and validation of reference genes in rabbit oocytes and preimplantation stage embryos. BMC Mol Biol 9: 67.

MARTIN, G.R. (1981). Isolation of a pluripotent cell line from early mouse embryos 
cultured in medium conditioned by teratocarcinoma stem cells. Proc Natl Acad Sci USA 78: 7634-7638.

NICHOLS, J., ZEVNIK, B., ANASTASSIADIS, K., NIWA, H., KLEWE-NEBENIUS, D., CHAMBERS, I., SCHOLER, H. and SMITH, A. (1998). Formation of pluripotent stem cells in the mammalian embryo depends on the POU transcription factor Oct4. Cell 95: 379-391.

NOWAK-IMIALEK, M., KUES, W.A., PETERSEN, B., LUCAS-HAHN, A., HERRMANN, D., HARIDOSS, S., OROPEZA, M., LEMME, E., SCHOLER, H.R., CARNWATH, J.W. et al., (2011). Oct4-enhanced green fluorescent protein transgenic pigs: a new large animal model for reprogramming studies. Stem Cells Dev 20: 1563-1575.

OEDA, S., HAYASHI, Y., CHAN, T., TAKASATO, M., AIHARA, Y., OKABAYASHI, K., OHNUMA, K. and ASASHIMA, M. (2013). Induction of intermediate mesoderm by retinoic acid receptor signaling from differentiating mouse embryonic stem cells. Int J Dev Biol 57: 383-389.

OKAMOTO, S. and TAKAHASHI, M. (2011). Induction of retinal pigment epithelial cells from monkey iPS cells. Invest Ophthalmol Vis Sci 52: 8785-8790.

OSTEIL, P., TAPPONNIER, Y., MARKOSSIAN, S., GODET, M., SCHMALTZ-PANNEAU, B., JOUNEAU, L., CABAU, C., JOLY, T., BLACHERE, T., GOCZA, E. et al., (2013). Induced pluripotent stem cells derived from rabbits exhibit some characteristics of naive pluripotency. Biol Open 2: 613-628.

PACHECO-TRIGON, S., HENNEQUET-ANTIER, C., OUDIN, J.F., PIUMI, F., RENARD, J.P. and DURANTHON, V. (2002). Molecular characterization of genomic activities at the onset of zygotic transcription in mammals. Biol Reprod 67: 1907-1918.

PESCE, M., WANG, X., WOLGEMUTH, D.J. and SCHOLER, H. (1998). Differential expression of the Oct-4 transcription factor during mouse germ cell differentiation. Mech Dev 71: 89-98.

PFEIFFER, M.J., BALBACH, S.T., ESTEVES, T.C., CROSETTO, N. and BOIANI, M. (2010). Enhancing somatic nuclear reprogramming by Oct4 gain-of-function in cloned mouse embryos. Int J Dev Biol 54: 1649-1657.

RUIZ, S., PANOPOULOS, A.D., MONTSERRAT, N., MULTON, M.C., DAURY, A., ROCHER, C., SPANAKIS, E., BATCHELDER, E.M., ORSINI, C., DELEUZE, J.F. et al., (2012). Generation of a drug-inducible reporter system to study cell reprogramming in human cells. J Biol Chem 287: 40767-40778.

SCALDAFERRI, M.L., FERA, S., GRISANTI, L., SANCHEZ, M., STEFANINI, M., DE FELICI, M. and VICINI, E. (2011). Identification of side population cells in mouse primordial germ cells and prenatal testis. Int J Dev Biol 55: 209-214.

SCHULTZ, R.M. (1993). Regulation of zygotic gene activation in the mouse. Bioessays 15: $531-538$

SHI, J.J., CAI, D.H., CHEN, X.J. and SHENG, H.Z. (2008). Cloning and characterization of the rabbit POU5F1 gene. DNA Seq 19: 56-61.

SHIMIZU, T., NAKAI, K., MORIMOTO, Y., ISHIHARA, M., OISHI, H., KIKUCHI, M. and ARAI, H. (2009). Simple rabbit model of vulnerable atherosclerotic plaque. Neurol Med Chir (Tokyo) 49: 327-332.

STAESSEN, C., JANSSENSWILLEN, C., DE CLERCK, E. and VAN STEIRTEGHEM, A. (1998). Controlled comparison of commercial media for human in-vitro fertilization: Menezo B2 medium versus Medi-Cult universal and BM1 medium. Hum Reprod 13: 2548-2554.

SUMER, H., NICHOLLS, C., LIU, J., TAT, P.A., LIU, J.P. and VERMA, P.J. (2010). Comparison of reprogramming ability of mouse ES and iPS cells measured by somatic cell fusion. Int J Dev Biol 54: 1723-1728.

TAKAHASHI, K., TANABE, K., OHNUKI, M., NARITA, M., ICHISAKA, T., TOMODA, K. and YAMANAKA, S. (2007). Induction of pluripotent stem cells from adult human fibroblasts by defined factors. Cell 131: 861-872.

TAKAHASHI, K. and YAMANAKA, S. (2006). Induction of pluripotent stem cells from mouse embryonic and adult fibroblast cultures by defined factors. Cell126:663-676.

THOMSON, J.A., ITSKOVITZ-ELDOR, J., SHAPIRO, S.S., WAKNITZ, M.A., SWIERGIEL, J.J., MARSHALL, V.S. and JONES, J.M. (1998). Embryonic stem cell lines derived from human blastocysts. Science 282: 1145-1147.

WANG, S., TANG, X., NIU, Y., CHEN, H., LI, B., LI, T., ZHANG, X., HU, Z., ZHOU, Q. and JI, W. (2007). Generation and characterization of rabbit embryonic stem cells. Stem Cells 25: 481-489.

WUENSCH, A., HABERMANN, F.A., KUROSAKA, S., KLOSE, R., ZAKHARTCHENKO, V., REICHENBACH, H.D., SINOWATZ, F., MCLAUGHLIN, K.J. and WOLF, E. (2007). Quantitative monitoring of pluripotency gene activation after somatic cloning in cattle. Biol Reprod 76: 983-991.

YEOM, Y.I., FUHRMANN, G., OVITT, C.E., BREHM, A., OHBO, K., GROSS, M. HUBNER, K. and SCHOLER, H.R. (1996). Germline regulatory element of Oct-4 specific for the totipotent cycle of embryonal cells. Development 122: 881-894.

YOSHIMIZU, T., SUGIYAMA, N., DE FELICE, M., YEOM, Y.I., OHBO, K., MASUKO, K., OBINATA, M., ABE, K., SCHOLER, H.R. and MATSUI, Y. (1999). Germlinespecific expression of the Oct-4/green fluorescent protein (GFP) transgene in mice. Dev Growth Differ 41: 675-684.

YOUN, H., KIM, S.H., CHOI, K.A. and KIM, S. (2013). Characterization of Oct4-GFP spermatogonial stem cell line and its application in the reprogramming studies. J Cell Biochem 114: 920-928.

ZOU, J., MALI, P., HUANG, X., DOWEY, S.N. and CHENG, L. (2011). Site-specific gene correction of a point mutation in human iPS cells derived from an adult patient with sickle cell disease. Blood 118: 4599-4608.

ZUCCOTTI, M., MERICO, V., BELLI, M., MULAS, F., SACCHI, L., ZUPAN, B., REDI, C.A., PRIGIONE, A., ADJAYE, J., BELLAZZI, R. et al., (2012). OCT4 and the acquisition of oocyte developmental competence during folliculogenesis. Int $\lrcorner$ Dev Biol 56: 853-858. 


\section{Further Related Reading, published previously in the Int. J. Dev. Biol.}

Induction of intermediate mesoderm by retinoic acid receptor signaling from differentiating mouse embryonic stem cells. Oeda, S., Hayashi, Y., Chan, T., Takasato, M., Aihara, Y., Okabayashi, K., Ohnuma, K. and Asashima, M. (2013). Int J Dev Biol 57: 383-389.

OCT4 and the acquisition of oocyte developmental competence during folliculogenesis.

Zuccotti, M., Merico, V., Belli, M., Mulas, F., Sacchi, L., Zupan, B., Redi, C.A., Prigione, A., Adjaye, J., Bellazzi, R. et al., (2012). Int J Dev Biol 56: 853-858.

Identification of side population cells in mouse primordial germ cells and prenatal testis. Scaldaferri, M.L., Fera, S., Grisanti, L., Sanchez, M., Stefanini, M., De Felici, M. and Vicini, E. (2011).

Int J Dev Biol 55: 209-214.

Comparison of reprogramming ability of mouse ES and iPS cells measured by somatic cell fusion.

Sumer, H., Nicholls, C., Liu, J., Tat, P.A., Liu, J.P. and Verma, P.J. (2010).

Int J Dev Biol 54: 1723-1728.

Enhancing somatic nuclear reprogramming by Oct4 gain-of-function in cloned mouse embryos.

Pfeiffer, M.J., Balbach, S.T., Esteves, T.C., Crosetto, N. and Boiani, M. (2010) Int J Dev Biol 54: 1649-1657.

Common culture conditions for maintenance and cardiomyocyte differentiation of the human embryonic stem cell lines, BG01 and HUES-7.

Denning, C., Allegrucci, C., Priddle, H., Barbadillo-Munoz, M.D., Anderson, D., Self, T., Smith, N.M., Parkin, C.T. and Young, L.E. (2006).

Int J Dev Biol 50: 27-37.

5 yr ISI Impact Factor $(2011)=2.959$
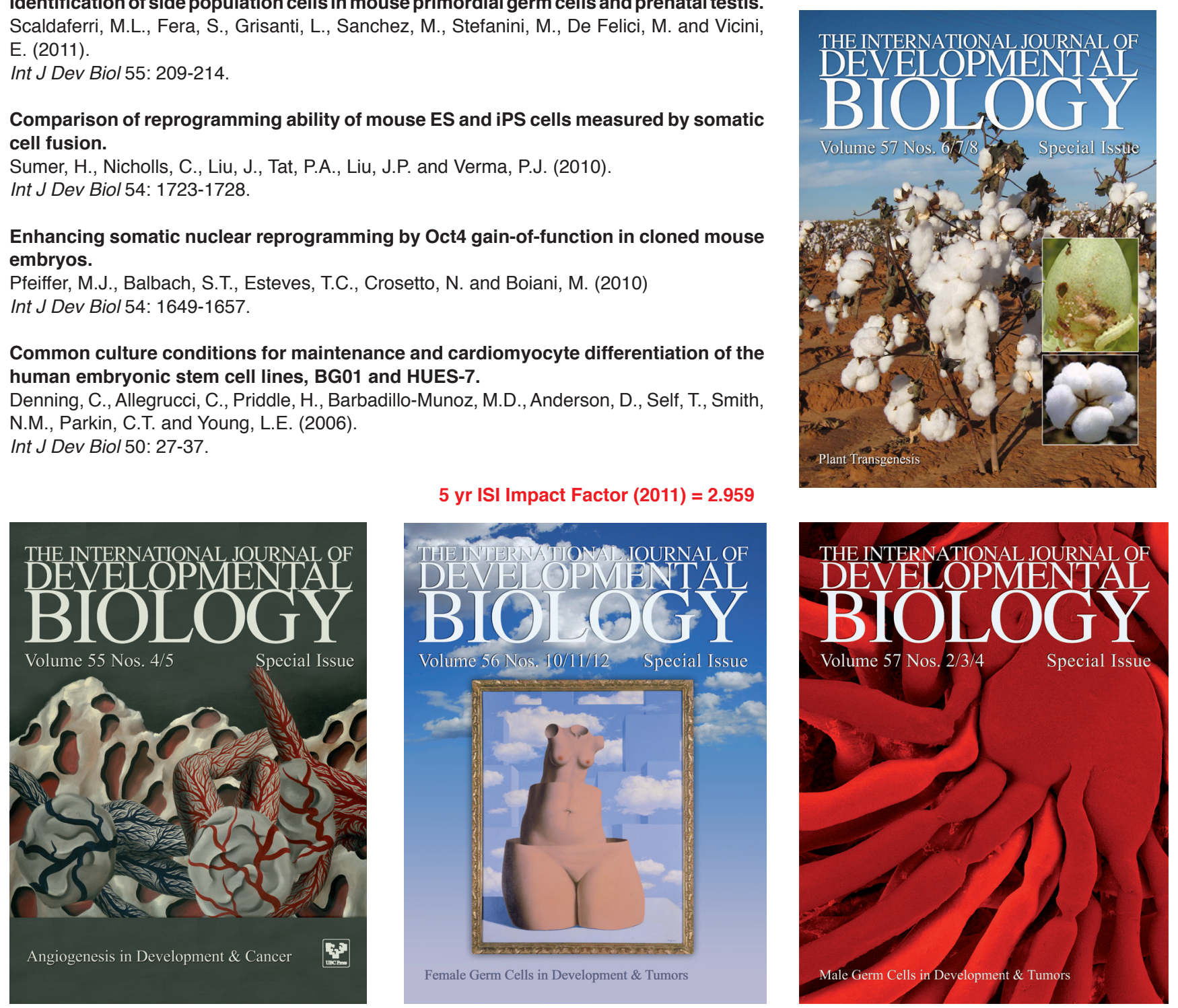